\title{
Correction to: Influences of service characteristics and older people's attributes on outcomes from direct payments
}

Vanessa Davey ${ }^{1,2}$

\author{
Correction to: BMC Geriatr 21, 1 (2021) \\ https://doi.org/10.1186/s12877-020-01943-8
}

Following publication of the original article [1], the author notified about the errors in article text body. The correct sentences should be as follows:

Older people living alone reported outcome gains 22\% lower than older people living with others (Table 4). Taking into account current hourly home care costs, $(£ 16.04,20)$ this equates to roughly $16.5 \mathrm{~h}$ of state funded social care per week in 2018-2019, versus $17 \mathrm{~h}$ a week for the sample based on average unit home care costs in $2006(£ 11,40)$.

Published online: 16 April 2021

\section{Reference}

1. Davey. Influences of service characteristics and older people's attributes on outcomes from direct payments. BMC Geriatr. 2021;21:1. https://doi.org/1 0.1186/s12877-020-01943-8.

\footnotetext{
The original article can be found online at https://doi.org/10.1186/s12877020-01943-8.

Correspondence: vanessa.davey@vhir.org

${ }^{1}$ Research Fellow, Re-FIT Research Group, Parc Sanitari Pere Virgili \& Vall

d'Hebrón Institute of Research (VHIR), Barcelona, Spain

${ }^{2}$ Formerly at Personal Social Services Research Unit (PSSRU), London School

of Economics \& Political Science (LSE), London, UK
}

(c) The Author(s). 2021 Open Access This article is licensed under a Creative Commons Attribution 4.0 International License, which permits use, sharing, adaptation, distribution and reproduction in any medium or format, as long as you give appropriate credit to the original author(s) and the source, provide a link to the Creative Commons licence, and indicate if changes were made. The images or other third party material in this article are included in the article's Creative Commons licence, unless indicated otherwise in a credit line to the material. If material is not included in the article's Creative Commons licence and your intended use is not permitted by statutory regulation or exceeds the permitted use, you will need to obtain permission directly from the copyright holder. To view a copy of this licence, visit http://creativecommons.org/licenses/by/4.0/ The Creative Commons Public Domain Dedication waiver (http://creativecommons.org/publicdomain/zero/1.0/) applies to the data made available in this article, unless otherwise stated in a credit line to the data. 